\title{
EFFECT OF METAPHORICAL THINKING LEARNING ON IMPROVING ABILITY OF MATHEMATICAL UNDERSTANDING VIEWED FROM INTEREST LEVEL OF STUDENT LEARNING
}

\author{
Nurkolis $^{1}$, Jejen Abdul Fatah ${ }^{2}$, Hoer Mutaqin ${ }^{3}$ \\ ${ }^{1}$ MA Teladan Al-Kalam Cianjur \\ 2 SMA YWKA Bandung \\ ${ }^{3}$ SMK Negeri 1 Klari Karawang \\ ${ }^{1}$ nurkolis1327@gmail.com, ${ }^{2}$ jen.adlfa@gmail.com, ${ }^{3}$ hoer.mutaqin @ gmail.com
}

Received: June, 2018; Accepted: June, 2018

\begin{abstract}
This study aims to obtain a picture of improving the ability of mathematical understanding on the implementation of learning with metaphorical thinking approach in terms of student interest level. The method used in this research is experiment with factorial design $3 \times 2$. The population is all high school students in Cianjur Regency with the sample subject is two classes of X in one of senior high school in Cianjur environment. The first class gets learning with metaphorical thinking approach, and the second class gets instruction with direct intruction model. From the research, it can be concluded that there is no difference in the improvement of mathematical understanding among high school students who get the learning with Metaphorical Thinking and Direct Instruction approach. There is a difference in the increase of mathematic understanding among the students whose interest level is high with medium, low, and low with high, there is no interaction between the learning model and the level of student's learning interest in improving the ability of mathematical understanding.
\end{abstract}

Keywords: Mathematical Understanding, Interest in Learning, Metaphorical Thinking Approach .

\begin{abstract}
Abstrak
Penelitian ini bertujuan untuk memperoleh gambaran tentang peningkatan kemampuan pemahaman matematik pada implementasi pembelajaran dengan pendekatan metaphorical thinking ditinjau dari tingkat minat belajar siswa. Metode yang digunakan penelitian ini adalah eksperimen dengan desain factorial $3 \times 2$. Populasinya adalah seluruh siswa sekolah menengah atas di Kabupaten Cianjur dengan subjek sampelnya adalah dua kelas X di salah satu sekolah menengah atas di lingkungan Cianjur. Kelas pertama mendapat pembelajaran dengan pendekatan metaphorical thinking, dan kelas kedua mendapat pembelajaran dengan model direct intruction. Dari penelitian diperoleh kesimpulan bahwa tidak terdapat perbedaan peningkatan kemampuan pemahaman matematik antara siswa sekolah menengah atas yang memperoleh pembelajaran dengan pendekatan Metaphorical Thinking dan Direct Instruction, terdapat perbedaan peningkatan kemampuan pemahaman matematik antara siswa yang tingkat minatnya tinggi dengan sedang, sedang dengan rendah, dan rendah dengan tinggi, tidak terdapat interaksi antara model pembelajaran dan tingkat minat belajar siswa tehadap peningkatan kemampuan pemahaman matematik.
\end{abstract}

Kata Kunci: Pemahaman Matematik, Minat Belajar, Pendekatan Metaphorical Thinking

How to Cite: Nurkolis., Fatah, J. A., Mutaqin, H. (2018). Effect Of Metaphorical Thinking Learning On Improving Ability Of Mathematical Understanding Viewed From Interest Level Of Student Learning. JIML, 1 (2), 110-115. 


\section{INTRODUCTION}

In the process of learning mathematics mathematical understanding is a very important part, because one of the goals in learning mathematics is the understanding of students from each concept that has been submitted, because by understanding what has been learned, students can better understand the concept of mathematics subject matter, and will tend inherent in student's memory.

NCTM (2000) detailing mathematical understanding includes the ability to: define verbal and written concepts; create examples and non examples; presenting a concept with models, diagrams and symbols; change a form of representation to another form of representation; recognize the various meanings and interpretations of concepts; identify the properties of a concept and recognize the conditions that define a concept; compare and differentiate concepts.

Sumarmo (Hendriana, 2009) says the vision of developing mathematics learning to meet the present needs of mathematics learning needs to be directed to understanding the concepts and principles of mathematics that are then needed to solve mathematical problems, problems in other disciplines and problems in everyday life.

The success of a person's learning can be influenced by several factors, both from within and outside the concerned, one of the factors in a person that may affect learning outcomes is interest in learning. Higher learning interests make it easier for students to achieve learning goals, while lack of interest in learning can lead to a lack of interest in a particular field (Hendriana, Dkk, 2017)

According to Chotimah (2010) Interest in learning is the psychological aspect of a person who manifests itself in several symptoms, such as: desire, feeling like to conduct the process of behavior change through various activities that include seeking knowledge and experience, in other words, interest in learning is attention, likes, interests of a person (learners) of the learning that is shown through keantusiasan, participation and activeness in learning.

Metaphorical Thingking is a concept of thinking that emphasizes the relationship of mathematics and real phenomena. Metaphor as the basic concept of thinking. Metaphorical thinking is a thinking process that uses metaphors to understand a concept (Roesdiana, 2016)

The results of Carreira's study (Hendriana, 2012) say that the application of mathematical problems in real phenomena provides its own conditions to produce meaning and understanding in the mathematical concept. Meanwhile, according to Holyoak \& Thagard (Hendriana, 2009), the metaphor moves from a concept known to students to other concepts that have not been known or are being studied by students.

By using metaphorical thinking students can see the relationship between concepts he learned with the concepts he knows. Through Metaphorical Thinking concepts in mathematics can be presented with interesting and presentation of mathematical material can be reduced level of abstraction, thus helping to simplify students' thinking to understand the concept of mathematics.

From all the above descriptions the authors are interested in researching the Influence of Metaphorical Thinking Learning on Improving Mathematical Understanding Ability Viewed From the Interest Level of Student Learning

\section{METHOD}

The method of this study was quasi experiments, with researchers taking two classes for the research sample. First class gets learning with metaphorical thinking approach, and second class 
112 Nurkolis., Fatah,J.A., Mutaqin,H.. Effect Of Metaphorical Thinking Learning On Improving Ability Of Mathematical Understanding Viewed From Interest Level Of Student Learning

gets direct learning. Before and after the treatment of both classes were given the same treatment of the ability of mathematical understanding. With the factorial design as follows:

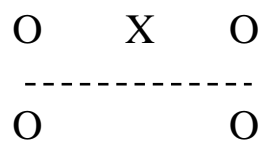

Note :

$\mathrm{O}:$ Pretest $=$ postest mathematical understanding ability

$\mathrm{X}$ : Learning with metaphorical thinking approach

- - - : The sampling is not subject random

Population in this research is all student of senior high school in Cianjur Regency with subject of sample is two class $\mathrm{X}$ in one of senior high school in Cianjur environment.

The data analyzed in this research is the normalized gain data (n-gain) of students' mathematical understanding with the help of SPSS 21 . The test used is two way anova test.

\section{RESULTS AND DISCUSSION}

\section{Results}

The result of descriptive analysis of the index data of the gain of both classes is shown in the following table:

Table 1. Descriptive Statistics of n-gain Mathematical Understandng Ability

\begin{tabular}{ccccccc}
\hline Class & N & Max. Value & $\begin{array}{c}\text { Min. } \\
\text { Value }\end{array}$ & Mean & $\begin{array}{c}\text { standard } \\
\text { deviation }\end{array}$ & Varians \\
\hline Experimental & 30 & 0.750 & 0.286 & 0.493 & 0.1237 & 0.015 \\
Control & 31 & 0.700 & 0.262 & 0.467 & 0.1306 & 0.017 \\
\hline
\end{tabular}

Based on Table 1 it can be seen that the average gain index obtained by the experimental class students of 0.493 means that the experimental class has a moderate understanding of mathematical comprehension, and the average gain index of the control class students is 0.467 . It means that the class also has an improved mathematical understanding ability moderate. The average value of the experimental gain class index is higher than the average value of the control class gain index. Thus it can be concluded that the improvement of students' mathematical understanding ability of the class using learning with metaphorical thinking approach is better than the class that uses the learning with direct instruction model.

Based on the data analysis of mathematical understanding ability, then obtained the data as follows:

Table 2. Improve Score Students who Study with Metaphorical Thinking and Direct Intruction Approach in Review of Student Learning Interest Level

\section{Approach}

Metaphorical Thinking Direct Intruction

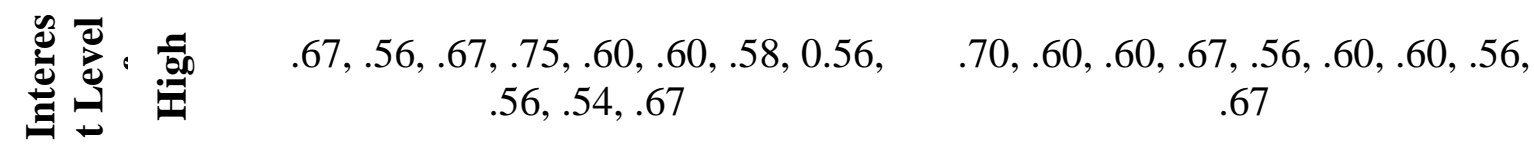




\begin{tabular}{|c|c|c|}
\hline & \multicolumn{2}{|c|}{ Approach } \\
\hline & Metaphorical Thinking & Direct Intruction \\
\hline$\underset{\Xi}{\Xi}$ & $\begin{array}{c}.50, .55, .54, .54, .55, .45, .48, .48 \text {, } \\
.50\end{array}$ & $\begin{array}{c}.35, .45, .48, .50, .50, .58, .42, .54 \\
.42, .54, .55\end{array}$ \\
\hline ف) & $\begin{array}{c}.31, .42, .42, .29, .38, .33, .33, .31 \\
.31, .38\end{array}$ & $\begin{array}{c}.32, .32, .38, .31, .26, .44, .31, .29 \\
.29, .38, .31\end{array}$ \\
\hline
\end{tabular}

Score data seen in Table 2. above is used to test the hypothesis in the following studies:

Hypothesis 1: There is a difference in the improvement of mathematical understanding among senior high school students who gain learning with metaphorical thinking approach and Direct Instruction

Hypothesis 2: There is a difference in improving the ability of mathematical understanding between students whose level of interest; high, medium, and low

Hypothesis 3: There is an interaction effect between the learning model and the level of student learning interest in improving the ability of mathematical understanding

Two-way Anova test result using SPSS (Statistical Product and Service Solution) software version 21.0 for Windows, with significance level $\alpha=0,05$. shown in the following table:

Table 3. Results of Anova Two Path Test of Gain Mathematical Understanding Ability

\begin{tabular}{lrrrrr}
\hline Source & $\begin{array}{c}\text { Type III Sum } \\
\text { of Squares }\end{array}$ & Df & Mean Square & \multicolumn{1}{c}{ F } & Sig. \\
\hline Corrected Model & $.802^{\mathrm{a}}$ & 5 & .160 & 53.926 & .000 \\
Intercept & 14.110 & 1 & 14.110 & 4742.018 & .000 \\
Medel_Pembelajaran & .003 & 1 & .003 & .982 & .039 \\
Tingkat_Minat & .791 & 2 & .396 & 132.936 & .000 \\
Medel_Pembelajaran* & .003 & 2 & .001 & .454 & .038 \\
Tingkat_Minat & & & & & \\
Error & .164 & 55 & .003 & & \\
Total & 15.011 & 61 & & & \\
Corrected Total & .996 & 60 & & & \\
\hline a R Squared & & & & &
\end{tabular}

a. R Squared $=.831$ (Adjusted R Squared $=.815$ )

The first will be seen the influence of MT and DI learning model on improving students' mathematical understanding ability. Based on Table 4.8 line (learning model) it is seen that Sig. is .326. This value meets the Sig criteria. > .05 then the average ability of mathematical understanding between class MT and DI is the same (there is no significant difference), or in other words there is no difference in improving the ability of mathematical understanding between students who gain learning with metaphorical thinking approach and direct instruction.

Next will be seen the influence of the level of student interest in learning to improve students' understanding ability. Based on Table 4.8 line (interest level) it is seen that Sig. is .000 . The value meets Sig criteria. $\leq .05$ then the average ability of mathematical understanding between the level of interest is not the same (there are significant differences), or in other words there is 
114 Nurkolis., Fatah,J.A., Mutaqin,H.. Effect Of Metaphorical Thinking Learning On Improving Ability Of Mathematical Understanding Viewed From Interest Level Of Student Learning

at least one interest rate group different from the others in terms of improving the ability of mathematical understanding.

To know which groups of students with different levels of interest differed significantly in their mathematical understanding skills, followed by Scheffe test. The results are shown in the following table:

Table 4. Scheffe Test Results N-Gain Mathematical Understanding Ability

\begin{tabular}{llccccc}
\hline $\begin{array}{l}\text { (I) Level of } \\
\begin{array}{l}\text { Learning } \\
\text { Interest }\end{array}\end{array}$ & $\begin{array}{l}\text { Learning } \\
\text { Interest }\end{array}$ & $\begin{array}{c}\text { Mean } \\
\text { Difference } \\
(\mathbf{I}-\mathbf{J})\end{array}$ & $\begin{array}{c}\text { Std. } \\
\text { Error }\end{array}$ & Sig. & \multicolumn{2}{c}{$\begin{array}{c}\text { 95\% Confidence Interval } \\
\text { Lower Bound } \\
\text { Upper Bound }\end{array}$} \\
\hline \multirow{2}{*}{ High } & Medium & $.11895^{*}$ & .017250 & .000 & .07555 & .16235 \\
& Low & $.27759^{*}$ & .017043 & .000 & .23471 & .32047 \\
\multirow{2}{*}{ Medium } & High & $-.11895^{*}$ & .017250 & .000 & -.16235 & -.07555 \\
& Low & $.15864^{*}$ & .017043 & .000 & .11576 & .20152 \\
\multirow{2}{*}{ Low } & High & $-.27759^{*}$ & .017043 & .000 & -.32047 & -.23471 \\
& Low & $-.15864^{*}$ & .017043 & .000 & -.20152 & -.11576 \\
\hline
\end{tabular}

Based on observed means.

The error term is Mean Square(Error) $=.003$.

*. The mean difference is significant at the .05 level.

Based on Table 4 . above shows that the three levels of interest have a sig value. $\leq .05$, so it can be concluded that the three levels of interest (high, medium, and low) there are significant differences. Furthermore, it will be seen the effect of interaction collectively between the learning model and the level of interest in learning to improve students' mathematical understanding ability.

Based on Table 3. line (interest rate* model) seen Sig value. is .638. The value meets Sig. > .05 then there is no significant interest rate interaction between metaphorical thinking and direct intruction class. This means that there is no significant difference for students who gain learning with metaphorical thinking and direct intruction on mathematical understanding ability. In general, metaphorical thinking approach does not give a significant influence on the level of interest in improving the ability of mathematical understanding

\section{Discussion}

The improvement of students 'learning outcomes is seen in the $\mathrm{N}$-gain of mathematical understanding ability which shows the improvement of students' learning outcomes after the learning is done in the class using the metaphorical thinking approach has an average of .493, whereas in the class using Direct Intruction model learning has average .467. In other words, improving the ability of mathematical understanding in the classroom that use the learning with Metaphorical Thinking approach is better than the improvement of mathematical understanding ability in the class that use the learning with Direct Intruction model. This is in line with research conducted by Miftahul Jannah Khotip with the title "Improvement of Mathematics and Mathematics Communication Understanding through learning with Metaphorical Thinking 
approach" shows that learning with metaphorical thingking approach can improve mathematical understanding.

Learning with metaphorical thinking approach stabbed an opportunity for students to explore with various metaphors to express their understanding of a concept and given the widest freedom to dare to express ideas and construct their own knowledge because of student-centered learning activities, where the teacher only becomes a facilitator who acts as a guide in teaching and learning activities in the classroom. In contrast to direct instruction learning, learning is still teacher-centered, students accept only what the teacher says, and students do not have enough opportunity to present ideas that they have

\section{CONCLUSION}

Based on the results of research on differences in the ability of understanding and communication of mathematics in terms of the level of learning interest of students whose learning using the approach of Metaphorical Thinking and Direct Instruction obtained the following conclusions: There is no difference in improving the ability of mathematical understanding among MA students who received learning with the approach of Metaphorical Thinking and Direct Instruction. There is a difference in improving the ability of mathematical understanding among students whose level of interest; high, medium, and low. There is no interaction between the learning model and the level of student learning interest in improving the ability of mathematical understanding

\section{REFERENCES}

Chotimah, E. C. (2010) Upaya Meningkatkan Minat Belajar Peserta Didik dalam Mata Pelajaran PAI Materi Sholat Melalui Perpaduan Model Pembelajaran Card Sort dan Pap (Picture and Picture) di Kelas IV SDN Jatingaleh 03 Semarang. Skripsi pada Institut Agama Islam Negeri Walisongo Semarang.

Hendriana, H. (2009). Pembelajaran Dengan Pendekatan Metaphorical Thinking untuk Meningkatkan Kemampuan Pemahaman Matematik, Komunikasi Matematik dan Kepercayaan Diri Siswa Sekolah Menengah Pertama. Disertasi pada Sekolah Pasca Sarjana Unipersitas Pendidikan Indonesia.

Hendriana, H. (2012). "Pembelajaran Matematika Humanis Dengan Metaphorical Thinking Untuk Meningkatkan Kepercayaan Diri Siswa” dalam Jurnal Ilmiah Program Studi Matematika STKIP Siliwangi Bandung. Vol. 1 No.1 Februari 2012.

Hendriana, H., Rohaeti, E., dan Sumarmo, U. (2017) Hard Skills dan Soft Skills Matematik Siswa. Bandung: Refika Aditama.

Roesdiana, L. (2016) "Pembelajaran dengan Pendekatan Metaphorical Thinking untuk Mengembangkan Kemampuan Komunikasi dan Penalaran Matematis Siswa" dalam Jurnal Pendidikan Uiniversitas Singaperbangsa Karawang, November 2016 